\title{
„Poczuj historię. Plenerowe Laboratorium Archiwalne” jako przyklad tematycznej imprezy na wolnym powietrzu Archiwum Narodowego w Krakowie
}

Z okazji obchodów XII Międzynarodowego Dnia Archiwów w dniu 8 czerwca 2019 r. Archiwum Narodowe w Krakowie zorganizowało w swojej siedzibie przy ul. Siennej 16 dzień otwarty. W programie znalazła się m.in. prezentacja oryginałów trzech bezcennych obiektów z zasobu Archiwum: księgi ławniczej miasta Krakowa (najstarsza zachowana księga miejska zawierająca zapisy z lat 1300-1375), pieczęci majestatycznej króla Kazimierza Wielkiego z XIV w. i dokumentu królowej Jadwigi Andegaweńskiej z 7 stycznia 1385 r. zezwalającego Spytkowi z Lisowa na przeniesienie wsi Lisów na prawo niemieckie.

Materiały eksponowane były w sali czytelni Oddziału III Archiwum. Jednocześnie na dziedzińcu budynku przy ul. Siennej 16 ustawiony został namiot, w którym zorganizowano (w godzinach 12.00-19.00) strefę edukacyjną pod hasłem „Poczuj historię. Plenerowe Laboratorium Archiwalne". W tak zaaranżowanej przestrzeni wydzielono trzy stanowiska tematyczne (oznakowane graficznie), w obrębie których pracownice Archiwum (Bożena Lesiak-Przybył, Anna Sokół, Aldona Warzecha) - w nawiązaniu do równolegle eksponowanych oryginalnych obiektów, dzieliły się wiedzą o metodach i technikach wykonania oraz znaczeniu, funkcji i zdolności prawnej historycznych wytworów kancelarii (takich jak dokument, księga czy pieczęć). Na wszystkich stoiskach prowadzono jednocześnie otwarte wykłady tematyczne z elementami warsztatów i instruktaży, z wykorzystaniem materiałów, narzędzi i innych rekwizytów pozwalających zilustrować i zademonstrować wybrane zagadnienia w praktyce. Taki był podstawowy cel i założenie wydarzenia, mające odzwierciedlenie w jego nazwie, aby uczestnicy mogli omówić interesujące ich tematy w bezpośredniej rozmowie z archiwistami, a przede wszystkim - zdobyć wiedzę i konkretne umiejętności w praktyce, w sposób interaktywny i eksperymentalny, wykonując własnoręcznie określone czynności i zadania.

Pierwsze stoisko - „Zapisane na skórze - średniowieczny dokument” poświęcone zostało budowie i formie dawnych dokumentów, pracy i warsztatowi pisarza, w tym materiałom pisarskim. Odwołując się do prezentowanego dokumentu królowej Jadwigi wystawionego dla Spytka z Lisowa, poruszano tu zagadnienia związane z paleografią, dyplomatyką, działalnością królewskiej kancelarii, osobą samej królowej czy kwestiami średniowiecznego prawa lokacyjnego. Na przykładzie dokumentu królowej Jadwigi objaśniano m.in. jego formuły (protokół, kontekst i eschatokół, z wyodrębnieniem dalszych części), język, rodzaj i dukt pisma, systemy abrewiacji. Prezentowane były wybrane materiały i narzędzia pisarskie (m.in. papirus, pergamin, papier czerpany oraz pióra ptasie i stalówki), omawiano metody ich wytwarzania (np. proces produkcji pergaminu czy sposoby zacinania pióra gęsiego) oraz warsztat pracy pisarza, ilustrowany reprodukcjami grafiki i malarstwa z epoki. Uczestnicy mogli spróbować swoich sił w czytaniu historycznych dokumentów czy kaligrafii. 
Drugim punktem na mapie „Laboratorium” było stanowisko zatytułowane „Władcy zaklęci w wosku - królewskie pieczęcie”, koncentrujące się na tematyce sfragistycznej. Zainteresowani goście mogli zdobyć wiedzę w zakresie genezy, funkcji i znaczenia pieczęci jako środka uwierzytelniającego. Analizowano elementy pola pieczętnego i systematykę wyobrażeń pieczętnych. Przybliżano historyczne sposoby wytwarzania pieczęci, metody i techniki ich łączenia z dokumentem, zabezpieczenia autentyczności, czy też formy przechowywania i zabezpieczenia pieczęci i tłoków. Archiwiści odwoływali się do oryginalnych pieczęci prezentowanych podczas wydarzenia - pieczęci majestatycznej Kazimierza Wielkiego, eksponowanej w formie pieczęci luźnej oraz unikatowej pieczęci majestatycznej królowej Jadwigi przywieszonej do dokumentu z 1385 r. - ilustrując omawiane tematy m.in. przerysami obu pieczęci, reprodukcjami zbiorów sfragistycznych Archiwum i innych zabytków czy rekwizytami (takimi jak lak czy wosk pszczeli, plastyczne modele pieczęci oraz współczesne tłoki). W ramach ćwiczeń praktycznych uczestnicy instruktażu mieli okazję wykonać własnoręcznie pieczęcie (lakowe, opłatkowe, tuszowe), co spotkało się z dużym zainteresowaniem, a czasem wręcz entuzjazmem (zwłaszcza młodszych odwiedzających).

Tematyka ostatniego stoiska, pod nazwą „Od deski do deski - średniowieczne księgi miejskie", koncentrowała się wokół kwestii związanych z bibliologią historyczną. Archiwiści przybliżali budowę historycznych ksiąg, techniki ich wytwarzania, używane do tego narzędzia i materiały, etapy ich produkcji. Punktem wyjścia dla zilustrowania tej problematyki w odniesieniu do książki rękopiśmiennej była prezentowana w tym czasie w sali czytelni najstarsza księga miejska Krakowa. W kontekście poruszanych tematów dodatkowym walorem był fakt, że księga została spisana na pergaminie, a ponadto zachowała się w formie pozwalającej na identyfikację i rozpatrzenie na jej przykładzie wielu zagadnień związanych z budową książki rękopiśmiennej (doskonale widoczne są w niej np. wyraźne liniowania wierszy). Dodatkowo omawiano działalność kancelarii miejskich, ich sposób funkcjonowania, wytwory (ze szczególnym uwzględnieniem rodzajów i serii ksiąg wytwarzanych w krakowskiej kancelarii oraz treści zapisków najstarszej księgi krakowskiej). Zgłębiano również kwestie dotyczące wynalezienia druku i związanych z tym zmian w procesie produkcji książki. Przekazywanie informacji ułatwiały zgromadzone pomoce (w tym elementy i narzędzia warsztatu introligatorskiego), które pozwalały na pokazanie wybranych zjawisk w praktyce.

Oprócz tych trzech miejsc, dla najmłodszych przygotowano dodatkowe stoisko - z materiałami do zabawy (puzzle i kolorowanki archiwalne oraz inne gry graficzne i językowe oparte na materiałach z zasobu Archiwum). Ponadto młodsze dzieci otrzymywały na początku wizyty kolorowe naklejki z grafiką identyfikującą wydarzenie.

Zaproponowana forma spotkania z użytkownikami archiwów i miłośnikami historii była pierwszym tego typu doświadczeniem dla Archiwum i stanowiła swojego rodzaju eksperyment w zakresie sposobu organizacji imprez otwartych. Celowo zrezygnowano z popularnej formy wykładu czy prelekcji na rzecz otwarcia się na bezpośredni kontakt i rozmowę z odwiedzającymi, proponując wykonywanie zadań praktycznych. Tematy dyskusji zostały określone w luźnych ramach. Myślą przewodnią były zagadnienia sygnalizowane w nazwach stoisk, jakkolwiek rozległe spektrum zainteresowań i wiedzy uczestników powodowało, że każda rozmowa toczyła się w inny, i tylko w niewielkim stopniu przewi- 
dywalny, sposób. Dla prowadzących „Plenerowe Laboratorium Archiwalne” stanowiło to duże wyzwanie - wymagało elastyczności i spontaniczności, a nierzadko moderacji dyskusji pomiędzy gośćmi. Oprócz dbałości o poziom merytoryczny przekazywanych treści, na barkach archiwistów spoczywał też ciężar zainteresowania prezentowanym tematem, wciągnięcia odwiedzających do rozmowy i zachęcenia do zgłębiania wiedzy. Było to szczególnie trudne, gdyż wszystkie stanowiska, a każde miało wiele do zaoferowania, zgromadzone zostały na niewielkiej przestrzeni dziedzińca budynku przy ul. Siennej 16. Efekt jednakże przerósł oczekiwania organizatorów, okazało się, że właśnie w takiej bezpośredniej i nieformalnej atmosferze możliwe jest przekazanie pokaźnej dawki wiedzy w sposób precyzyjnie odpowiadający potrzebom odbiorców. Bo to właśnie uczestnicy, dzięki możliwości porozmawiania $\mathrm{z}$ archiwistami i zadawania pytań, w rzeczywistości określali kierunek rozwoju każdej z prowadzonych z opiekunami stanowisk rozmów. Taka forma kontaktu pozwoliła odwiedzającym na wyrażanie własnych zainteresowań i potwierdziła, jak wiele osób interesuje się historią i archiwaliami. A przede wszystkim była dla organizatorów dowodem, że archiwa są magnesem nie tylko dla profesjonalistów - naukowców czy wyspecjalizowanych w poszukiwaniach genealogów, ale w równym stopniu dla amatorów, którzy w wielu wypadkach nie mieli okazji samodzielnie korzystać z zasobu archiwalnego, jednak prezentowane zagadnienia okazały się dla nich interesujące. Dla takich osób ciekawy jest zasób archiwalny i to, co się w nim kryje, ale także praca archiwistów czy konserwatorów, owiana pewną aurą tajemniczości ze względu na wąską specjalizację i niewielką medialność.

Bezpośrednia forma spotkania podczas „Laboratorium” miała jeszcze jeden, niespodziewany efekt. W trakcie rozmów z uczestnikami związanych z prezentowanymi zagadnieniami archiwiści natychmiast otrzymywali informację zwrotną na temat postrzegania imprezy oraz sugestie i propozycje tematów przyszłych spotkań. Dzięki temu wiadomo, że odbiór „Laboratorium” był bardzo pozytywny i że jest zapotrzebowanie na tego typu bezpośredni kontakt z Archiwum i pracującymi w nim specjalistami. Pozwala to na wniosek, że Archiwum powinno częściej angażować się w organizację tego typu wydarzeń otwartych i że kolejne przygotowane w takiej formie spotkania mają również szansę zyskać duże zainteresowanie.

Anna Sokót, Aldona Warzecha Archiwum Narodowe w Krakowie 